\title{
A concepção de democracia predominante no Serviço Social brasileiro a partir da década de 1980
}

\author{
The conception of democracy prevailing in the Brazilian Social Work from the 1980s
}

\author{
Lourival Souza Felix ${ }^{1 *}$ \\ Claudia Neves da Silva ${ }^{2 * *}$
}

\begin{abstract}
Resumo
O artigo tem como objetivo analisar a concepção de democracia no Serviço Social brasileiro a partir da década de 1980. Para isso, foi realizada uma pesquisa bibliográfica com dois dos principais periódicos do Serviço Social de circulação nacional nas décadas de 1980 e 1990, para entender a concepção de democracia que se destacou entre as vanguardas da profissão ao longo das décadas pesquisadas. Verificou-se que a concepção de democracia foi dando lugar à defesa da democratização com a medida que consolidou o processo de transição democrática. Também foi possível verificar que a ideia de democracia forjada no interior da profissão estava vinculada aos diversos movimentos sociais destas décadas, que arrefeceu com a eleição de governos democráticos e populares e levou as críticas por parte da própria vanguarda da profissão. Nesse sentido, tanto a formulação da democracia posta como único caminho para construir o socialismo no Brasil, como a defesa da democratização, demonstrou sua inviabilidade em romper com o status quo.
\end{abstract}

Palavras-chave: Serviço Social. Democracia. Estado. Movimentos sociais.

\begin{abstract}
The article aims to analyze the conception of democracy in the Brazilian Social Work from the 1980s. For this, a bibliographical research was carried out with two of the main periodicals of the Social Work of national circulation in the 1980s and 1990s, to understand the conception of democracy that stood out among the vanguards of the profession during the decades researched. It was found that the conception of democracy was giving rise to the defense of democratization as it consolidated the process of democratic transition. It was also possible to verify that the idea of democracy forged within the profession was like to the various social movements of these decades, which cooled with the election of democratic and popular governments and led to criticism by the very vanguard of the profession. In this sense, both the formulation of democracy as the only way to build socialism in Brazil, and the defense of democratization, demonstrated its inability to break with the status quo.
\end{abstract}

Keywords: Social Work. Democracy. State. Social Movement.

\footnotetext{
1* Mestre em Serviço Social e Política Social. Professor do curso de Serviço Social na UNESPAR - Campus Paranavaí e na União de Faculdades Metropolitanas de Maringá/UNIFAMMA.

2** Doutora em História. Professora Associada do Departamento de Serviço Social e do Programa de PósGraduação em Serviço Social e Política Social da Universidade Estadual de Londrina.
} 


\section{Introdução ${ }^{3}$}

No debate acadêmico que se consolidou na década de 1980 (período da redemocratização), caracterizado pela ocupação dos espaços organizativos por uma nova vanguarda profissional (CRESS/CFESS; ABESS/ABEPSS), se destaca a preocupação de determinar os rumos profissionais em torno de uma definição política que tem no seu núcleo a defesa da democracia, entendida como o postulado político a ser defendido e também como condição para desenvolvimento de novos projetos societários alternativos aos das classes dominantes (PAULO NETTO, 2008).

A concepção de democracia como núcleo do projeto profissional aparece sendo "considerada a democratização como socialização da participação política e socialização da riqueza socialmente produzida" (PAULO NETTO, 2008, p. 16). Esta referência explicitada no contexto da transição democrática a partir de 1979 foi constituída no desenvolvimento da concepção de democracia como único meio para o socialismo, posteriormente assumindo uma perspectiva de democratizar o Estado burguês.

Esta perspectiva política, no entanto, não é apresentada com toda clareza como o que é, ou seja, uma determinada posição política, disputando com as outras diversas perspectivas. Pelo contrário, é apresentada na literatura predominante como expressão da orientação geral da profissão, de toda ela, de todos os assistentes sociais e, ainda, não sob a forma de uma posição política, mas da materialização da "ética profissional", o que facilita a sua penetração no ideário corrente dos assistentes sociais.

Este é mais um motivo pelo qual, em geral, a democracia política não é questionada como um princípio político, mas tende a ser assimilado de modo acrítico, às vezes até dogmático.

Também a democracia política tem sido apresentada neste debate como a manifestação particular da perspectiva marxista, quer dizer, a democracia seria o caminho para a classe operária (na verdade, o que aparece na literatura são classes "subalternas" ou "trabalhadora", expressões diversas às que a teoria marxista formulou), alcançar uma sociedade sem "exploração de classe, etnia e gênero" (raramente se fala em socialismo e

\footnotetext{
3 Este artigo é uma versão condensada do terceiro capítulo da Dissertação de Mestrado "A concepção de democracia no serviço social brasileiro pós - 1980", defendida em agosto de 2018, no Programa de PósGraduação em Serviço Social e Política Social da Universidade Estadual de Londrina. A pesquisa foi realizada com o apoio do CNPq, por meio de bolsa Demanda Social.
} 
muito menos em comunismo). O recurso ao marxismo tem neste cenário a função de conferir autoridade teórica e ideológica ao postulado político.

Partindo destas considerações, tem-se por objetivo analisar a concepção de democracia no Serviço Social brasileiro a partir da década de 1980. Esta pesquisa caracteriza-se como bibliográfica e seu universo foram 9 artigos distribuídos nas seguintes revistas: Revista Serviço Social e Sociedade 6; e Caderno ABESS 3. O último artigo, de autoria de José Paulo Netto (2008), foi utilizado dado sua importância no meio profissional.

Não se tem por intenção verificar a relação entre democracia e marxismo, mas a influência da formulação de que a democracia seria o único caminho para o socialismo no Brasil, em uma conjuntura de transição democrática cujo desenvolvimento levou à defesa do governo "democrático e popular" nos anos 2003-2016.

O contexto de reorganização e reinserção da classe operária com destaque para o movimento sindical e político em defesa da redemocratização da sociedade brasileira influenciou setores que constituem as vanguardas do Serviço Social, colocando-se numa perspectiva crítica frente à ditadura militar (1964 a 1985) e pela redemocratização.

De acordo com Paulo Netto (2011), o movimento que conferiu a uma parcela da categoria profissional um nível de politização mais qualificado e avançado, teve momentos e lugares. Momentos se referem ao período que se inicia na década de 1970 e atravessa a década de 1980. Lugares diz respeito à inserção de assistentes sociais em movimentos sociais, associações de moradores, sindicatos, organizações da categoria, universidade, dentre outros.

No âmbito universitário, Paulo Netto (2011) afirma que de meados da década de 1970 até meados de 1980 o Serviço Social sofreu expansão e avanços no campo teórico e metodológico e uma aproximação com a teoria "marxista":

\footnotetext{
Numa palavra: a partir de meados dos anos de 1980, patenteia-se que a perspectiva da intenção de ruptura não é apenas um vetor legítimo do processo de renovação do Serviço Social no Brasil - evidencia-se o seu potencial criativo, instigante e, sobretudo, produtivo (PAULO NETTO, 2011, p. 267).
}

Cabe também destacar, segundo lamamoto (2013), que o próprio Serviço Social enquanto profissão, é considerado a partir de sua historicidade e passa a fazer parte de um balanço crítico que evidencia suas dimensões ideo-teóricas, culminando no 
aprofundamento da "teoria social crítica". Isto se expressa nos anos 1980 e avança na década seguinte, marcado pela crítica ao marxismo vulgar e sob aspectos teóricos e metodológicos frente ao conservadorismo profissional.

\section{A perspectiva das vanguardas do Serviço Social frente ao Movimento Popular}

Primeiramente, é importante ressaltar que o período analisado constitui o da transição de uma ditadura militar (1964-1985) para a redemocratização; isto será decisivo na própria formulação e defesa da democracia no interior do Serviço Social. Momento que contava com a presença de amplos setores da classe operária e organizações populares vinculados às lutas sociais pela efetivação de outra forma de organização do Estado que não fosse à ditadura militar. A transição a qual se está referindo, inclusive, dinamizada no final da década de 1970 por iniciativa dos próprios militares, determinada pela crise econômica e contando com o protagonismo dos "trabalhadores, os setores populares, [que] colocam-se como força social no cenário político" (CARVALHO, 1985, p. 20).

Sobre a transição da ditadura ter ocorrido mediante um processo lento e gradual, cujos interesses eram de setores dirigentes entre os militares e da própria burguesia nacional e imperialista ou ter sido derrotada pela classe operária e setores populares, afirma Paulo Netto (2008, p. 9):

\footnotetext{
A resistência à ditadura, conduzida no plano legal por uma frente de oposição hegemonizada por segmentos burgueses descontentes, ganhou profundidade e qualidade novas quando, na segunda metade dos anos 1970, a classe trabalhadora se reinseriu na cena política, por meio da mobilização dos operários metalomecânicos do cinturão industrial de São Paulo (o “ABC paulista").
}

A ditadura militar que já vinha mostrando sinais de esgotamento por conta da crise econômica, foi pressionada por setores da burguesia nacional e internacional para realizar a transição democrática, em fins dos anos 1970 e início de 1980 . Conformou uma transição sem grandes alterações no que diz respeito às relações de classes: burguesia e proletariado. Embora, sob a democracia enquanto regime político do Estado brasileiro, a organização do movimento operário e movimentos sociais como um todo atingem um grau de liberdades democráticas jamais visto - particularmente em ditadura militar. Há também a afirmação que para a transição ocorrer, foi decisivo o acirramento das lutas sociais a partir da organização de setores da classe operária, campesinato e populares (a 
exemplo, o movimento sindical, movimentos de trabalhadores rurais que em 1984 constituiu o Movimento dos Trabalhadores Sem Terra - MST, movimentos em defesa de creches, asfalto, etc.) os quais levaram a um maior grau de politização a ponto de alguns autores afirmarem que a ditadura tinha sido derrotada - o que em uma dada medida ocorreu!

Segundo Luiz Eduardo Wanderley (1985), a transição que estava ocorrendo, efetivamente era uma transição que não garantia a penetração dos interesses dos trabalhadores, pelo contrário, era um movimento feito por cima da classe operária e oprimida.

Contudo, ressalta Wanderley $(1985$, p. 10$)$, houve a necessidade de "eleger, se possível, representantes populares que vão defender esses temas na próxima Constituição, buscando introduzir essas coisas novas, ao menos uma democracia social efetiva." Esse desenho inicial acerca da perspectiva da necessidade de haver uma "democracia efetiva" foi sendo desenvolvida e canalizada pelo Movimento Popular:

\footnotetext{
O grande projeto do movimento popular é negar esse sistema e lutar pela construção de um outro. Mas isso não está claro na consciência da maioria do movimento popular e sim de setores e lideranças. Ele hoje luta pela sua própria sobrevivência: comer, morar, ter saúde. Dar esse passo qualitativo para a construção de um projeto de uma nova sociedade é o vetor, o norte desse movimento popular (WANDERLEY, 1985, p. 11).
}

A perspectiva apontada requer explicitar a estratégia para o movimento popular "projeto de uma nova sociedade" (o autor não se refere qual sociedade especificamente). A ênfase é para dois tipos de reformas: primeira "uma reforma agrária inteligente e bem executada é a base para combater a miséria e melhorar o nível de vida"; segunda “reforma fundamental é no setor do trabalho. Quer dizer, garantir o direito ao trabalho" (WANDERLEY, 1985, p. 11).

Essas reformas estão no plano tático do movimento popular e fazem parte da conquista de uma democracia que deve ser constituída numa perspectiva contrária ao que vem sendo forjada como democracia no Brasil. Por isso, ao se referir as duas reformas, elas são "só embriões da nova sociedade que nós queremos construir, na direção de uma democracia que vem de baixo para cima e não de cima para baixo" (WANDERLEY, 1985, p. 12). 
Nesse sentido, o desenvolvimento do que vem sendo colocado, canaliza para a relação de construção dessa "nova sociedade" com o Estado, ou seja, na linha de pensamento do autor, o movimento popular é o portador do projeto de transformação da sociedade em que se vive, e para constituir uma sociedade nova, requer criar um novo Estado democrático efetivo às massas trabalhadoras e populares.

De acordo com Cardoso (1990), a relação dos movimentos sociais urbanos com o Estado se coloca em um campo minado, por um lado considerando o papel político de caráter transformador dos movimentos sociais, por outro lado, a função do Estado que no capitalismo tem o objetivo primário de preservar a propriedade privada.

Os movimentos sociais urbanos se organizam a partir de suas necessidades básicas e coletivas, habitação, transporte, saneamento:

\begin{abstract}
Dadas as necessidades provenientes da realidade urbana, esses movimentos se organizam, quase sempre, em função de problemas locais e de interesses imediatos, procurando resistir às condições de vida a que são submetidas, formulando inúmeras reivindicações dirigidas ao Estado, que é visto como o único capaz de entendê-las, uma vez que é ele quem determina as políticas sociais para o atendimento das populações, assim como normatiza, regula e intervém junto às mesmas (CARDOSO, 1990, p. 25).
\end{abstract}

Ao se referir aos "grupos populares" que compõem os movimentos sociais populares enquanto agentes da transformação da ordem estabelecida, Cardoso (1990) considera tais setores de trabalhadores como o núcleo orgânico desse movimento:

Quando nos referimos aos grupos populares, estamos entendendo os setores majoritários da sociedade que vivem uma condição de exploração e dominação determinada pelas contradições geradas pelo capitalismo. Tal concepção compreende, portanto, o operariado, o campesinato [...] (CARDOSO, 1990, p. 22).

Desta forma, os movimentos sociais populares têm suas origens e seus fundamentos assentados nas contradições que são expressões da relação capital e trabalho. O grau de desenvolvimento ou surgimento de novas organizações do proletariado e de setores populares estão submetidas às relações de classes no ordenamento burguês, ou seja, o próprio desenvolvimento capitalista no Brasil, a exemplo, o industrial, formou a classe operária, a qual se opõe ao processo de exploração da força de trabalho. 
Segundo Cardoso (1990), a partir da análise de Eder Sader, em "11 teses sobre autonomia", os movimentos devem defender sua independência de classe frente às organizações da burguesia e seu Estado. Não se trata de cada um fazer o que quer, pelo contrário, diz respeito quanto a preservação da autonomia, mas com conteúdo classista e democrático acerca da defesa dos direitos dos trabalhadores. Esta autonomia colocada principalmente em oposição aos "modelos socialistas" que, na perspectiva de Cardoso (1990), se constituiu no processo de degeneração e burocratização de inspiração estalinista, limitaram o alcance do potencial dos movimentos sociais populares numa perspectiva de transformação:

\begin{abstract}
A valorização, pelo autor, do papel da autonomia dos movimentos sociais populares no processo de transformação social vincula-se diretamente à crise dos "modelos socialistas", entendida, numa primeira abordagem, como a constatação de uma degenerescência das sociedades pós-revolucionárias, onde havia projetos socialistas, como também a constatação de conservadorismo, burocratismo, sectarismo e elitismo das organizações partidárias criadas para serem instrumentos da revolução e da libertação social (CARDOSO, 1990, p. 16).
\end{abstract}

$\mathrm{Na}$ perspectiva apontada, a verificação dos elementos que de certa forma bloquearam o avanço rumo a uma sociedade socialista, posteriormente à Revolução Russa de outubro em 1917 cujo desenvolvimento já a partir da década de 1920 foi marcada pelo burocratismo e sobretudo pela defesa do socialismo num só país, de acordo com Cardoso (1990, p. 17) ficou hipotecada ao "desvio do Stalinismo em relação ao leninismo." O desenvolvimento desta análise levou a justificarem a existência de "crise do socialismo".

Para Cardoso (1990), ao referenciar Sader, há que pensar os próprios modelos de socialismo considerando os novos processos históricos que vêm se constituindo. Um elemento central diz respeito ao partido político que dará direção à luta dos movimentos populares

[...] o verdadeiro partido revolucionário deve ter o papel de sistematizar experiências, elaborar propostas para a luta política, impulsionar a unidade e a autonomia dos movimentos sociais dos explorados e oprimidos, para que as massas se capacitem e façam frente à ordem do Estado burguês (CARDOSO, 1990, p. 18).

De acordo com Cardoso (1990), a preocupação com relação ao partido tem por finalidade questionar a separação radical entre os militantes profissionais e os movimentos sociais cujos encaminhamentos das lutas nos processos revolucionários 
estavam subordinados às vanguardas políticas, distante e separada dos movimentos das massas.

Sobre a autonomia defendida, há uma concepção de democracia subjacente que é seu chão histórico e começa a aparecer à medida que vão se desenvolvendo os próprios aspectos políticos e organizativos dos movimentos sociais nos momentos de luta numa perspectiva revolucionária. Porém, ao colocar a autonomia dos movimentos, é preciso ater-se ao seu conteúdo. Ao citar Sader, Cardoso (1990, p. 20) diz

[...] o conteúdo e a realização da perspectiva da autonomia do movimento popular são a preparação de um processo político que levará à extinção ou separação do Estado e projetará um Estado de transição em que esse processo se realize como expansão da democracia, das liberdades políticas e da participação de todos na gestão da coisa pública.

A concepção de autonomia que pressupõe a democracia como explicitado acima, estava posta numa conjuntura política de organização do movimento popular dos anos 1980, em que ocorria a luta pela democratização do Estado, visto por alguns autores e correntes políticas como o prosseguimento das lutas sociais à conformação de um período que corresponderá à "expansão da democracia, das liberdades políticas e da participação de todos na gestão da coisa pública" (CARDOSO, 1990, p. 20). Neste caso, a própria referência na citação, não autoriza afirmar que a perspectiva de "expansão da democracia" subsidiará os elementos para a constituição da ordem socialista no Brasil.

Neste processo, segundo Cardoso (1990), a autonomia guarda relação com dois níveis: primeiro, o mais elementar é a autonomia dos movimentos sociais locais, que não podem estar pautados na espontaneidade e tampouco se subordinar às reivindicações específicas (isso não quer dizer que eles não tenham) de caráter corporativos; caso isso aconteça, ocorrerá a separação entre reivindicações do trabalho e da política; segundo, elevará o nível da formação política e organizativa para haver o adensamento entre as reivindicações que sejam de ordem concreta dos trabalhadores.

Ainda de acordo com Cardoso (1990), há que privilegiar a autonomia dos movimentos com relação a sua participação, inclusive ao se tratar do Estado. Segundo advertência de Nascimento (1986) quanto ao período em que estava vivendo, embora formalmente a ditadura militar tenha entrado em um processo de esgotamento e transitado para uma forma democrática, ainda permanecem aspectos autoritários que 
inviabilizam ou manipulam a participação popular no interior das instituições do Estado. Contudo, o autor enfatiza a importância da participação para defender suas necessidades:

Na perspectiva democrática, o mais justo, talvez, seja não se abster de participar de propostas, mas entrar no jogo, tentando desenvolver as potencialidades democráticas que elas contêm, numa aliança com os setores mais democráticos da sociedade civil (NASCIMENTO, 1986, p. 15).

Esta perspectiva democrática estava relacionada ao seu contraponto, isto é, à ditadura militar; o movimento popular tinha reivindicações de longa data, como transporte, habitação, creches e escolas dentre outras, e agora começa a se postular que "o mais justo, talvez, seja... entrar no jogo, tentando desenvolver as potencialidades democráticas que elas contêm, numa aliança com os setores mais democráticos da sociedade civil" (NASCIMENTO, 1986, p. 15) o que embutia uma outra compreensão da democracia, não mais justificada como "caminho ao socialismo", mas como espaço em que seria possível conquistar as reivindicações populares. Vê-se uma gradual transformação daquilo que seria meio em fim.

Segundo Gohn (1985), de 1975 a 1979 os movimentos sindicais e de bairros eram dirigidos por seus próprios núcleos internos. Esta relação começa a sofrer alterações profundas com as eleições de 1982, que se refletiu em uma relação entre os movimentos com os partidos políticos. Num primeiro momento, há implicações no sentido de institucionalizarem as lutas "em decorrência deste ponto tem-se uma certa institucionalização de vários movimentos populares que antes pressionavam o Estado e agora penetraram em seu bojo, a exemplo da Luta por Creches em São Paulo." (GOHN, 1985 , p. 21). Os efeitos disso não se colocam no plano bom ou ruim, mas da política e autonomia dos movimentos do que seria a defesa dos interesses das massas trabalhadoras.

A própria reformulação da vida partidária que teve início nos anos 1980 rebateu e provocou um refluxo e a fragmentação dos movimentos, além da institucionalização dos mesmos; e estes fatos refletiram na capacidade de luta e defesa de uma democracia interna dos setores organizados.

Contudo, aprofundaram as manifestações com relação a forma de articulação dos movimentos em prol da defesa de suas necessidades concretas e a vinculação do partido político com o movimento social, o que gerou algumas contradições no que concerne à organização, conforme destacou Gohn (1985, p. 22): 


\begin{abstract}
Para alguns segmentos das correntes políticas existentes, a organização deve vir da base, de baixo para cima. A forma como isso se daria, varia do espontaneísmo às táticas de nucleação e agregação dos indivíduos por regiões, categorias profissionais etc. Nesta corrente, os movimentos populares vão ser visto como fontes preciosas de organização na medida em que representam demandas reais a partir das próprias bases. Esta corrente encontra-se bastante disseminada no interior do Partido dos Trabalhadores/PT.
\end{abstract}

Esta relação "movimento-partido" causa discussões internas dos movimentos sociais entre as correntes políticas referente à institucionalização e autonomia das reivindicações de lutas. Segundo Cardoso (1990), inicia um processo que as lutas teriam de passar a depender das respostas do Estado, implicando em uma relação de dependência e refletindo em uma guinada à direita na medida que seus dirigentes vão se alinhando a adversários políticos. De acordo com Gohn (1985, p. 23): “A questão deixou de ser mobilizar a população para pressionar o governo, para ser colaborador em políticas participativas. Passou a ocorrer uma tendência a certa institucionalização dos movimentos".

Se comparado o conteúdo dessa citação com relação às análises de Cardoso, (1990), verifica-se um processamento e distanciamento com relação ao potencial político dos movimentos em face de seu papel questionador, ou seja, perdeu-se o caráter de organizador de setores de trabalhadores numa posição oposta ao Estado, para defender a participação popular dentro deste Estado.

Do ponto de vista dos segmentos sociais e das categorias profissionais, como a do Serviço Social, o contexto político da luta contra a ditadura militar e pela redemocratização expressou nas bandeiras dos movimentos sociais as suas reivindicações concretas, desde salário e condições de trabalho às melhorias nos bairros, como asfalto, creches dentre outros.

À medida que parte dos assistentes sociais estavam inseridos nos movimentos defendendo tais reivindicações, é necessário precisar as análises guardadas sobre as relações mais internas à profissão, no tocante a concepção de democracia e seus desdobramentos sobre o Serviço Social. Por isso analisar a concepção de democracia, principalmente, segundo José Paulo Netto (1986), sob sua redefinição para responder à realidade brasileira.

\title{
A redefinição da democracia para responder à realidade brasileira
}


Há que dar atenção a um texto de José Paulo Netto (1986) no qual faz uma síntese e proposta de redefinir a democracia, justificada a partir das condições sóciohistóricas da América Latina, logo do Brasil. Paulo Netto (1986) inicia com o reconhecimento de que o pressuposto da democracia política no ordenamento burguês está na base da igualdade jurídico-formal tendo como fundamento político a cidadania. Esta - a democracia - se colocou historicamente como uma necessidade possível e viável ao desenvolvimento das relações de produção capitalista, mesmo em uma perspectiva liberal.

Portanto, em países como os europeus, a democracia foi viável e implementada a partir dos interesses da burguesia. Nesse sentido, sobre o aspecto antidemocrático da burguesia brasileira, Nascimento (1986, p. 14) ressalta que, embora a democracia moderna seja uma criação da sociedade capitalista, isto não conduz a afirmação de que ela é da burguesia: "talvez fosse justo afirmar que ela se realiza quase que apesar da burguesia que não é intrinsecamente democrática; ela é forçada a sê-la ou adere por conveniência, segundo as circunstâncias."

O que Nascimento (1986) não mostra nesta abordagem é que a natureza de classe de um regime se define pela finalidade última dessa superestrutura, que é o Estado. A democracia é burguesa quando sua finalidade é a preservação da propriedade privada capitalista, ou seja, a apropriação privada dos meios de produção, condição essencial para a exploração da força de trabalho nos moldes capitalistas. O Estado burguês pode se organizar de modo mais democrático ou mais autoritário (ditaduras militares, fascismo, etc.), mas todas essas formas têm em comum a preservação da grande propriedade privada capitalista.

Nos países de economia atrasada como a do Brasil, subordinada ao imperialismo, a constituição da democracia não assegura a participação massiva da população. Pelo contrário, se constituiu no Brasil "um Estado que deve assegurar a heteronomia econômica (a subordinação ao imperialismo) pela exclusão das massas" (PAULO NETTO, 1986, p. 18). Por isso, a democracia é posta em prática pela burguesia em países como o Brasil, quando a centralização autoritária (ditaduras) esgota sua capacidade de organizar e harmonizar os interesses dos diversos setores da burguesia nacional e internacional no processo de acumulação capitalista. 
Portanto, "a democracia política entre nós, ergue-se não a partir de componentes do projeto burguês, mas da radicalização contra ele" (PAULO NETTO, 1986, p. 19). Ou seja, são os "subalternos" - expressão de Paulo Netto (1986) - e populares que têm a tarefa de construir a democracia no Brasil, daí a necessidade de redefini-la.

O conjunto de regras a partir da perspectiva jurídica que embasa a democracia do ponto de vista liberal "suporta-se na identidade entre cidadão e indivíduo (possuidor) e desemboca na socialização da política (não do poder político)" (PAULO NETTO, 1986, p. 22). A socialização do poder político que o "autor reivindica", diz respeito aos processos políticos da democracia que levam diretamente a um redimensionamento das instituições de poder que são contempladas pelo Estado e que vai passando a ser permeável aos interesses dos trabalhadores, tornando-se disfuncional à própria ordem burguesa. Nesta linha de pensamento, segue as análises de Cardoso (1990) ao se referir à política que deverá orientar os movimentos sociais nos processos de lutas e estabelecimento de alianças entre os trabalhadores e outros setores da sociedade civil.

Com isso, inicia a redefinição da democracia para atender os interesses dos trabalhadores e populares que ultrapassa uma posição ideológica. Essencialmente, o que se oculta aqui é o caráter burguês do ordenamento político-econômico. O autor sugere o elemento decisivo que é dar um novo conteúdo (não burguês) a essa democracia redefinida, a qual deverá orientar a "dinâmica das lutas de classes" no Brasil. Conforme Paulo Netto (1986, p. 23): “Entre nós, o núcleo democrático das ideologias se define não apenas como faculdade de incorporar valores sociais que se dão na dinâmica das lutas de classes, mas no tratamento que oferece as tendências prático-revolucionárias."

O sentido e o conteúdo da redefinição da democracia ganhariam um novo patamar, um caráter de classe novo, cuja finalidade seria a luta de classes numa perspectiva revolucionária. Nesse sentido, as lutas sociais em sociedades como a brasileira ganham um redirecionamento que a coloca na ordem do dia (PAULO NETTO, 1986). Se a democracia é o espaço do desenvolvimento de processos revolucionários que impulsionará os trabalhadores numa luta que ofereça condições para a revolução, o autor lembra que a democracia política é limitada.

Segundo Paulo Netto (1986), existe um "aparente paradoxo" a "democracia política, entre nós, é simultaneamente uma necessidade e um limite para o projeto histórico-emancipador da classe operária enquanto agente primordial da emancipação 
das classes e camadas subalternas" (PAULO NETTO, 1986, p. 23-24). Sobre a necessidade, diz respeito às condições políticas colocadas na América Latina, a qual a democracia política seria o único meio de avanço da luta dos trabalhadores frente aos imperativos do capital.

A democracia se apresentaria como modo viável de inserção dos trabalhadores nos processos político e social na constituição de uma política orientada para forjar um caminho que esteja subordinado aos interesses do proletariado e das camadas subalternas da sociedade brasileira.

Por outro lado, "é igualmente um limite, na proporção mesma em que o terreno político dos institutos cívicos é o da ordem social burguesa" (PAULO NETTO, 1986, p. 24). Ou seja, as instituições estatais que poderiam contribuir como núcleos de disseminação da democracia operária estão sob o comando da burguesia.

A expressão "aparente paradoxo" entre a necessidade e o limite da democracia política é de fato, segundo Paulo Netto (1986), aparente. Isto é, "o que se deve questionar particularmente entre nós é a possibilidade, nas nossas condições, de uma ordem burguesa não autocrática, de uma ordem burguesa permeável à redemocratização da sociedade e do Estado." (PAULO NETTO, 1986, p. 24). Por mais que o autor advirta quanto às burguesias assumirem o papel dirigente em processos políticos nas instituições do Estado, defende uma aliança entre setores da classe operária e populares com setores da burguesia nacional na luta por formas democráticas frente às formas de ditadura militar para organizar o Estado burguês.

Esse é um dos aspectos que vai forjando com a redefinição da democracia para justificá-la e aplicá-la na realidade brasileira por volta dos anos 1980. A política de aliança, embora com divergências internas entre os setores operários e populares que o compunham, predominava um aspecto central,

[...] toda aliança em torno da democratização formulava teoricamente seu caráter como o de uma luta contra o "Estado burocrático-autoritário". A derrota do "autoritarismo", inicialmente dos regimes militares, aparecia para alguns como um fim, para outros como uma etapa de transição no sentido da transformação radical da base produtiva da sociedade (CAMPOS, 1998, p. 10).

Esta concepção de democracia implica para a classe operaria e setores populares “forçar pela prática do jogo democrático e pela generalização da cidadania e, ao mesmo 
tempo, ilegitimar a ordem burguesa no próprio marco do ordenamento capitalista." (PAULO NETTO, 1986, p. 24). A orientação política neste momento conduz a uma política que concretamente resulte na - redefinição da democracia - aliança entre setores da sociedade brasileira, seja de setores alinhados à posição revolucionária, seja de setores estanhos à "esquerda".

De acordo com Paulo Netto (1986), a necessidade do expurgo de componentes autocráticos próprios do capitalismo e de seu Estado para a realização do processo simultâneo da socialização da política e da economia, seria no Brasil, uma construção promovida dentro dos marcos da sociedade burguesa:

Este expurgo é uma função da redefinição da democracia pelos segmentos populares e nacionais. Trata-se de promover a generalização dos institutos cívicos, ainda no marco do ordenamento capitalista, simultaneamente à ampliação de seu conteúdo. Mais concretamente: trata-se de postular, já agora, uma democracia política com claros rebatimentos econômicos e sociais - de postular e construir uma democracia de massas que se, desde já não pode ferir imediatamente o caráter de classe do Estado constituído, é organizável de baixo para cima, combinando a intervenção instituída com a instituinte (PAULO NETTO, 1986, p. 25-26, grifo nosso).

É possível afirmar, segundo o conteúdo da citação acima, que Paulo Netto (1986) está em concordância com a redefinição da democracia como meio para o socialismo com respaldo numa perspectiva "etapista". No desenvolvimento de seu artigo, a presença de alianças entre os "segmentos populares e nacionais" eram explícitos; não por acaso seus argumentos acerca da referida redefinição de democracia política num primeiro momento seria um pacto entre os setores da sociedade brasileira. Este pacto teria um caráter provisório, até que se criasse movimentos de massas que penetrariam nas instituições do Estado, como no parlamento, e em organizações como sindicatos, partidos, movimentos populares e profissionais.

Segundo o autor, esse movimento à princípio não excluiria a propriedade privada dos meios de produção capitalista, mas introduziria uma politização entre "o proletariado e as camadas subalternas" que desautorizaria e desacreditaria os monopólios estabelecidos, pois a redefinição da democracia política, sem romper o ordenamento capitalista, concebe três requisitos fundamentais para a transição socialista:

[...] abre a via para a democratização da sociedade e do Estado, introduz o proletariado e as classes e camadas subalternas nas atividades da gestão social e instaura uma dinâmica societária que permite vincular o mundo do trabalho ao mundo da cultura (PAULO NETTO, 1986, p. 26). 
A partir desta perspectiva, quanto à construção de uma democracia no marco da sociedade brasileira, que a vanguarda do Serviço Social se mobilizará.

\section{A perspectiva democratizante das vanguardas do Serviço Social}

A partir do final da década de 1970 ocorreram processos que alteraram e impactaram as análises acerca da democracia. A tentativa de Paulo Netto (1986) em redefini-la corresponde a um período de transição no qual as instituições do Estado estavam se reorganizando com a penetração de setores populares, mas também numa perspectiva da democracia burguesa canalizar as lutas que antes se davam nas ruas, para as "lutas" no parlamento.

Certamente essa canalização não levou todos os movimentos - operário, sindical, populares e camponês - a hipotecar suas reivindicações no parlamento e demais órgãos que, sendo o Estado burguês, responderam aos interesses burgueses, em que pese a penetração de representantes de setores populares. Contudo, segundo constatação de Cardoso (1990), houve um alinhamento político que se tornou predominante, isto é, as lutas deixaram de ser nas/das ruas, onde expressavam a maior possibilidade dos trabalhadores defenderem seus interesses, para o reconhecimento das "lutas" institucionalizadas em espaços da ordem burguesa, passando pelo crivo das eleições, como meio de atingir uma posição no Estado e influenciar, de alguma maneira, como representantes da população.

Esta perspectiva, embora flagrante mesmo em setores mais críticos do Serviço Social, foi predominante entre os setores operários, e em especial em setores populares contemplados por lideranças entre estudantes, lideranças de associação de bairro etc.

Também as vanguardas do Serviço Social aderiram com a institucionalização crescente das lutas populares:

[...] nos últimos cinco anos, no bojo do avanço da luta pela redemocratização do país, a luta pela hegemonia no Serviço Social também avança, explicitando-se, no processo de formação profissional, tendências no interior das forças sociais básicas com propostas políticas diversas (CARVALHO, 1985, p. 22).

E, no contexto desta democracia burguesa, precisam encontrar novas estratégias em ao referir-se à hegemonia na profissão, Carvalho (1985) estava olhando para 
estudantes e professores, que no interior da universidade "vem compondo uma vanguarda progressista" (CARVALHO, 1985, p. 23) em uma luta contra o conservadorismo profissional e em prol do Serviço Social crítico. Esta contraposição de setores críticos e setores conservadores ao longo dos anos 1980 forjou um projeto profissional com o objetivo de orientar tanto com a formação quanto ao exercício profissional. Este defende a vinculação aos movimentos sociais na defesa dos interesses da "clientela" e das lutas sociais.

No contexto da década de 1980, essa transformação marca a transição da ditadura militar para a democracia quando os interesses dos trabalhadores se colocam em outro plano para serem reivindicados, colocam-se "no âmbito da democracia burguesa, em que se configura a Nova República, a luta de classes assume formas distintas e específicas em relação ao longo período de ditadura" (CARVALHO, 1985, p. 34). Estas novas formas estão relacionadas aos movimentos sociais ocuparem os espaços da democracia burguesa e deles fazer um local de representação dos "interesses" dos trabalhadores.

Portanto, seguindo a linha de pensamento de Carvalho (1985), talvez o que mude é a compreensão dos espaços onde devem ser travados a luta de classes, não que a luta de classes assuma outras formas. Tanto é que suas análises estão respaldadas nos novos espaços, instituições que a democracia burguesa oferece e que os setores dos trabalhadores podem ocupar. Há uma relação com o Estado, que mesmo resguardada com a devida autonomia dos movimentos sociais gerais ou mesmo internos à profissão, reflete-se em novas estratégias:

E, no contexto desta democracia burguesa, precisam encontrar novas estratégias em termos de avançar nas suas lutas, aproveitando com lucidez e consciência os espaços que se vêm colocando ao nível dessa postura estratégica do Estado sem perder a sua autonomia e sua força de pressão (CARVALHO, 1985, p. 35).

As novas estratégias sugeridas por Carvalho (1985) se desenvolvem com a participação dos assistentes sociais em seus trabalhos, ou seja, de forma institucional via políticas socais na relação com os movimentos sociais construída numa perspectiva plural. Com isso, segundo Sposati (1992) há um campo a cumprir na construção da institucionalidade democrática. 
Nesta linha de argumentação, há que precisar o pluralismo, pois frequentemente ele é confundido com ecletismo no interior da profissão. Para além, ele subsidiará o espaço de debate profissional que se arrastou ao longo dos anos 1980 e contribuiu para as vinculações necessárias com organizações dos trabalhadores e demais setores populares formatando os espaços de debates. Portanto, o pluralismo

É sinônimo de abertura para o diferente, de respeito pela posição alheia, considerando que essa posição, ao nos advertir para com nossos erros e limites, e ao fornecer sugestões, é necessária ao próprio desenvolvimento da nossa posição e, de modo geral, da ciência (COUTINHO, 1987, p. 15).

A ideia de pluralismo foi elemento central para a constituição do já mencionado projeto profissional do Serviço Social, que ficou conhecido a partir do final da década de 1990 como projeto ético-político do Serviço Social brasileiro. Neste artigo, focou-se na concepção de democracia que implícita ou explicitamente permeava os debates internos à profissão. "Há que se reinventar o sentido e a esperança de uma relação libertária na busca da radicalidade democrática." (SPOSATI, 1992, p. 7).

Segundo Paulo Netto (2008), a ditadura concluiu seu curso a partir de aspectos internos, mas também de forma decisiva pela reinserção da classe operária se reorganizando em defesa da democratização, levando a um debate entre a parte conservadora e a parte crítica do Serviço Social:

\begin{abstract}
A luta pela democracia na sociedade brasileira, encontrando eco no corpo profissional, criou o quadro necessário para romper com o quase monopólio do conservadorismo no Serviço Social: no processo de derrota da ditadura se inscreveu a primeira condição - a condição política - para a constituição de um novo projeto profissional (PAULO NETTO, 2008, p. 10).
\end{abstract}

É evidente que sob um regime democrático, projetos como o do Serviço Social melhor se desenvolveria, até porque a sua proposta era romper com o conservadorismo profissional e a constituição de um novo projeto que orientasse tanto com a formação quanto à prática profissional.

Segundo Paulo Netto (2008), a partir da década de 1980 e se confirmando na de 1990, no meio profissional vem se acumulando alguns avanços na constituição de bases para a profissão. Ganha destaque o código de ética profissional, o avanço teórico metodológico com as sistematizações de pesquisas com as pós-graduações, que foram resultados de um longo debate político e profissional e dos avanços inscritos como 
resultado da redemocratização, a saber: "[...] à conquista de direitos cívicos e sociais que acompanhou a restauração democrática na sociedade brasileira." (PAULO NETTO, 2008, p. 14).

A linha democrática assumida pelas vanguardas do Serviço Social e que constituiu o interior do projeto ético-político estava vinculada ao movimento democrático e popular.

\begin{abstract}
Neste sentido, a construção deste projeto profissional acompanhou a curva ascendente do movimento democrático e popular que, progressivamente e positivamente, tensionou a sociedade brasileira entre a derrota da ditadura e a promulgação da Constituição de 1988 (à qual Ulisses Guimarães chamou de Constituição Cidadã) - um movimento democrático e popular que, inclusive apresentando-se como alternativa nacional de governo nas eleições presidenciais de 1989, forçou uma rápida redefinição do projeto democrático das classes proprietárias (PAULO NETTO, 2008, p. 18, grifo nosso).
\end{abstract}

A questão não é negar as conquistas democráticas, mas verificar que dentro do Estado burguês isso é permitido ora de formas mais alargadas, ora de formas restritas, de acordo com os interesses em disputas entre as classes fundamentais no capitalismo.

\title{
Considerações Finais
}

É possível inferir que ao longo do desenvolvimento do Estado burguês, a democracia foi uma das formas de organização das instituições estatais, resultando em conquistas das massas trabalhadoras no sentido dela passar a usar espaços do Estado, como o parlamento, para fazer a denúncia política e defender seus interesses enquanto classe no capitalismo, o que não exclui a questão central da democracia burguesa, qual seja: assegurar a propriedade privada capitalista.

No Brasil, com a redemocratização ocorrida ao longo da década de 1980, a democracia foi entendida como o único caminho para o socialismo, com a possibilidade de ampliar os espaços de luta dentro do Estado burguês. Incluía elevar politicamente as organizações dos trabalhadores - sindicatos, associações de moradores, movimento estudantil - e exigia a necessidade de um partido político assumir tal perspectiva.

Sob influência de setores progressistas da Igreja Católica, dos remanescentes dos grupos da luta armada e do novo sindicalismo foi criado o Partido dos Trabalhadores - PT. Como partido, o PT não assumiu o socialismo, mas setores importantes de sua vanguarda defenderam ser esse o partido a construir o socialismo no Brasil.

A postulação da democracia como o caminho para o socialismo e suas implicações posteriores não ficou apenas no plano dos partidos e organizações de 
trabalhadores, também integrou a orientação política de profissões, particularmente do Serviço Social brasileiro, a partir de profissionais que compuseram (algumas ainda compõem) setores da vanguarda profissional. Não se quer afirmar e muito menos negar a importância da democracia enquanto regime político de organização do Estado frente a situações em que o regime é uma ditadura militar - como a implantada no Brasil em 1964 e que se estendeu até 1985 . O que se pretende neste artigo é discutir a tese de que a democracia é o único caminho para o socialismo no Brasil.

A partir dos artigos pesquisados, pode-se verificar que ao longo dos anos 1980 houve a defesa do papel transformador dos movimentos sociais, os quais deveriam construir uma nova sociedade. Construção que viria por meios democráticos, ou seja, pela eleição, tendo em vista o contexto de transição democrática. Os autores defendiam as reformas sociais e institucionais, para posteriormente chegar a uma sociedade sem classes sociais.

As reformas sociais em determinados momentos são importantes para fins revolucionários numa perspectiva de táticas, já como estratégia/objetivo final para o Brasil, a questão se coloca na defesa da revolução operário e camponesa. A história demonstrou que a via pela democracia burguesa no máximo propiciou a democratização, a qual vive sendo assombrada pela ditadura militar (a conjuntura atual, com a eleição para cargos no Executivo e Legislativo de políticos alinhados à direita - e extrema direita reforça esta afirmação).

É importante destacar que houve, dentro do universo da pesquisa, divergências quanto às análises frente com a perspectiva que os movimentos sociais vinham assumindo durante a década de 1980 - a institucionalização destes movimentos - sobretudo quando da realização de eleições em que participaram novos partidos. Isto nos parece importante por haver uma concepção de Estado democrático e outra, a princípio, se colocando contrária à medida que questiona a tendência que se tomou com a institucionalização das reivindicações de luta, ampliando cada vez mais a partir da década seguinte.

O papel dos movimentos sociais quanto à transformação da sociedade via Estado burguês, na verdade, vai se institucionalizar ao ponto de eleger seus próprios representantes. À medida que os processos políticos avançam, há críticas quanto à perda de autonomia dos movimentos sociais - a pauta de luta dos movimentos deixa de ser reivindicações de suas bases para ser de suas direções, que se burocratizaram a ponto de 
aceitarem entrar no jogo democrático burguês. Isto resultou no alinhamento político de parte dos movimentos sociais, que de oposição ao Estado passou à defesa do mesmo Estado, o burguês.

\section{Referências}

CAMPOS, M. S. Democratização e desigualdade social no Brasil: notas sobre algumas implicações profissionais. Serviço Social e Sociedade, São Paulo, v. 19, n. 57, p. 9-27, jul. 1998.

CARDOSO, F. G. Os movimentos sociais populares no processo de transformação social. Serviço Social e Sociedade, São Paulo, v. 11, n. 33, p. 5-30, ago. 1990.

CARVALHO, A. M. P. O projeto de formação profissional do assistente social na conjuntura brasileira. Cadernos ABESS, São Paulo, n. 1, p. 17-42, 1985.

COUTINHO, C. N. Pluralismo: dimensões teóricas e políticas. Cadernos ABESS, São Paulo, n. 4, p. 5-17, set. 1987.

GOHN, M. G. M. Movimentos populares urbanos e democracia. Revista Serviço Social e Sociedade, São Paulo, n. 17, p. 15-29, abr. 1985.

IAMAMOTO, M. V. O Serviço Social na contemporaneidade: trabalho e formação profissional. 24. ed. São Paulo: Cortez, 2013.

NASCIMENTO, E. Participação: entre o autoritário e o democrático. Revista Serviço Social e Sociedade, São Paulo, n. 20, p. 6-15, abr. 1986.

PAULO NETTO, J. A construção do projeto ético-político do Serviço Social. In: MOTA, A. E. et al. (org.). Serviço Social e saúde: formação e trabalho profissional. São Paulo: Cortez, 2008. p. 1-22.

PAULO NETTO, J. A redefinição da democracia. Revista Serviço Social e Sociedade, São Paulo, n. 20, p. 17-27, abr. 1986.

PAULO NETTO, J. Ditadura e Serviço Social: uma análise do Serviço Social pós-64. 16. ed. São Paulo: Cortez, 2011.

SPOSATI, A. Serviço Social em tempos de democracia. Revista Serviço Social e Sociedade, São Paulo, n. 39, p. 5-31, ago. 1992.

WANDERLEY, L. E. Conjuntura, a universidade e o profissional. Cadernos ABESS, São Paulo, n. 1, p. 5-41, set. 1985. 